\title{
Addison's disease without pigmentation
}

\author{
T. J. Goodwin \\ M.B., M.R.C.P.
}

\author{
P. R. N. KIND \\ M.Sc., M.C.B., M.C.Path.
}

\author{
V. W. BOGOMOLETZ \\ M.D.(Geneva), M.C.Path. \\ St Mary's Hospital, London, W.9
}

\section{Summary}

Four cases of Addison's disease are described that presented without pigmentation. These cases were seen within an 8-month period in one hospital group.

\section{Introduction}

It has been said that pigmentation of the skin is the most distinctive feature of Addison's disease (British Medical Journal, 1963) and that no other clinical feature is as useful diagnostically (Dunlop, 1963). Four cases are presented where no pigmentation was found. The difficulties in diagnosis are discussed and it is suggested that Addison's disease without pigmentation is commoner than generally thought.

\section{Case no. 1}

\section{A.T. aged 30}

This patient was admitted on 2 April 1971 with a 3-week history of loss of appetite, fatigue and vomiting. There was an 8-year history of amenorrhoea, but she had one normal pregnancy in 1960.

On examination, she was a thin woman with no pigmentation. The breasts were small and axillary and pubic hair was scanty. BP 90/55. Pulse 76/min sinus rhythm. The heart, lungs and abdomen were normal.

Investigations. $\mathrm{Hb} 13.6 \mathrm{~g} / 100 \mathrm{ml}$, WBC 6600 , ESR $5 \mathrm{~mm} / 1 \mathrm{hr}$. Plasma electrolytes: blood urea $75 \mathrm{mg} / 100 \mathrm{ml}, \mathrm{Na} 127 \mathrm{mEq} / \mathrm{l}, \mathrm{K} 5.9 \mathrm{mEq} / 1, \mathrm{TCO}_{2}$ $23 \mathrm{mEq} / \mathrm{l}$. Urinary electrolytes: $\mathrm{Na} 74 \mathrm{mEq} / \mathrm{l}, \mathrm{K}$ $50 \mathrm{mEq} / \mathrm{l}$. Synacthen test $\left(\frac{1}{2} \mathrm{hr}\right)$ : resting plasma cortisol $4 \mu \mathrm{g} / 100 \mathrm{ml}$, 30-min level $4 \mu \mathrm{g} / 100 \mathrm{ml}$. Fasting blood sugar $55 \mathrm{mg} / 100 \mathrm{ml}$, 24-hr urinary 17 hydroxy steroids $1 \mathrm{mg} / 24 \mathrm{hr}$, plasma ACTH $1680 \mathrm{ng} / \mathrm{ml}$ (normal $70 \mathrm{ng} / \mathrm{ml}$ ), adrenal antibodiespositive, protein-bound iodine $5 \cdot 8 \mu \mathrm{g} / 100 \mathrm{ml}$.

Course and progress. 5 days after admission she became drowsy and hypotensive, BP 70/40. She was treated as an Addisonian crisis with intravenous normal saline and dexamethasone $8 \mathrm{mg}$. Further investigation was carried out, and she was found to have antibodies to thyroid, gastric parietal cells, and ovary. This is being investigated further and will be reported elsewhere. She remains well on a replacement therapy of cortisone $37.5 \mathrm{mg}$ and 9 alpha fluorohydrocortisone $0 \cdot 1 \mathrm{mg}$ daily.

\section{Case no. 2}

\section{P.U. aged 59}

This patient was admitted on 8 May 1971 following a fall whilst working at 20 feet. He had always been well in the past. There was no history of dizziness.

On examination, he was conscious and alert. There was no pigmentation. BP $110 / 60$. Pulse $74 / \mathrm{min}$ sinus rhythm. In the chest there were signs of multiple left rib fractures and a left pneumothorax. The abdomen and central nervous system were normal.

Investigations. Chest X-ray showed fractures of ribs $2-10$ on the left with a small pneumothorax. Skull X-ray-no fracture. Hb $14.4 \mathrm{~g} / 100 \mathrm{ml}$, WBC normal. Plasma electrolytes:

\begin{tabular}{lcccc}
\hline & Day 1 & Day 3 & Day 5 & Day 7 \\
\hline Blood urea $(\mathrm{mg} / 100 \mathrm{ml})$ & 37 & 27 & 30 & 42 \\
Na (mEq/l) & 120 & 115 & 116 & 108 \\
$\mathrm{~K}(\mathrm{mEq} / \mathrm{l})$ & $4 \cdot 7$ & $4 \cdot 1$ & $4 \cdot 3$ & $6 \cdot 2$ \\
$\mathrm{TCO}_{2}(\mathrm{mEq} / \mathrm{l})$ & 28 & 20 & 27 & 26 \\
\hline
\end{tabular}

Urinary electrolytes: Na $175 \mathrm{mEq} / \mathrm{l}, \mathrm{K} 24 \mathrm{mEq} / \mathrm{l}$. Plasma osmolarity $256 \mathrm{mmol} / 1$. Synacthen test $\left(\frac{1}{2} \mathrm{hr}\right)$ : resting plasma cortisol $10 \mu \mathrm{g} / 100 \mathrm{ml}, \frac{1}{2}-\mathrm{hr}$ level $6 \mu \mathrm{g} / 100 \mathrm{ml}$, repeated $\times 2$ with no response. Glucose tolerance test (Day 6): fasting $70 \mathrm{mg} / 100 \mathrm{ml}$, $96,85,55,60 \mathrm{mg} / 100 \mathrm{ml}$ at $\frac{1}{2}$ hourly intervals after $50 \mathrm{~g}$ glucose. 5-day Synacthen test-no response (Depot Synacthen $1 \mathrm{mg}$ daily for 5 days followed by a short Synacthen test). Adrenal antibodies-positive.

Course and progress. His rib fractures and pneumothorax were satisfactorily treated. His initial hyponatraemia suggested the possible diagnosis of an inappropriate secretion of ADH sometimes seen following severe head injury, but the follow-up electrolyte results together with a failure to respond to Synacthen confirmed a diagnosis of Addison's disease. 
He responded to replacement therapy, initially rather slowly, and is currently well on cortisone $37.5 \mathrm{mg}$ daily and 9 alpha fluorohydrocortisone $0 \cdot 1 \mathrm{mg}$ daily.

\section{Case no. 3}

\section{B.B. aged 79}

This patient was admitted on 2 September 1971 with an exacerbation of long-standing chronic bronchitis. He was treated with antibiotics and physiotherapy with fairly good results and he was discharged to convalescence 4 weeks later. In the past he had been treated for pulmonary tuberculosis in 1963 although no sputum cultures were positive. Two bronchoscopies of a right upper lobe shadow were normal. He used to smoke five cigarettes daily until June 1971.

On 25 October 1971 he was re-admitted with slurred speech, and with strange and at times violent behaviour.

Examination at that time showed a wasted man, with no pigmentation. He was deeply unconscious. BP $110 / 70$. Pulse rate $70 / \mathrm{min}$ sinus rhythm. There were no localizing CNS signs, but both plantar responses were extensor.

Investigations at that time. $\mathrm{Hb} 11.4 \mathrm{~g} / 100 \mathrm{ml}$, WBC 3600 , ESR $30 \mathrm{~mm} / 1 \mathrm{hr}$, blood urea $50 \mathrm{mg} / 100$ $\mathrm{ml}, \mathrm{Na} 125 \mathrm{mEq} / \mathrm{l}$, blood sugar $45 \mathrm{mg} / 100 \mathrm{ml}, \mathrm{K}$ $4.4 \mathrm{mEq} / \mathrm{l}$.

He was treated with intravenous dextrose $50 \%$ with recovery of consciousness over $2 \mathrm{hr}$ and complete recovery within 2 days. He was well on 26 October 1971. On 27 October he had a further period of hypoglycaemia (blood sugar $30 \mathrm{mg} / 100 \mathrm{ml}$ ) that again responded to intravenous dextrose. On 28 October further hypoglycaemia occurred (blood sugar $25 \mathrm{mg} / 100 \mathrm{ml}$ ) that again responded.

$\mathrm{He}$ again became profoundly unconscious on 2 November BP $110 / 70$ with a very poor response to intravenous dextrose.

Other investigations at that time showed: Plasma electrolytes: $\mathrm{Na} 107 \mathrm{mEq} / 1, \mathrm{~K} 4.2 \mathrm{mEq} / 1, \mathrm{TCO}_{2}$ $24 \mathrm{mEq} / \mathrm{l}$. Urinary electrolytes: $\mathrm{Na} 34 \mathrm{mEq} / \mathrm{l}, \mathrm{K}$ $25 \mathrm{mEq} / \mathrm{l}$. Plasma cortisol: 10.00 a.m. $5 \mu \mathrm{g} / 100 \mathrm{ml}$, 12.00 midnight $3 \mu \mathrm{g} / 100 \mathrm{ml}$.

A diagnosis of Addison's disease was made. He was treated with 31 of $5 \%$ dextrose with saline to which was added $150 \mathrm{mg}$ hydrocortisone. He was also given fludrocortisone $0.1 \mathrm{mg}$ daily. He responded initially, but died on 6 November 1971 .

Necropsy was performed 4 days after death. No abnormal external features were noted and in particular no pigmentation was present. Thorax. The heart was normal and the remainder of the cardiovascular system only showed mild atheromatous changes. In the respiratory system, the upper lobes were markedly adherent to the corresponding areas in both pleural cavities. The bronchial mucosa was markedly congested and there was marked bronchiectatic dilatation in the terminal bronchi on both sides. The apical portion of the right lung contained several irregular tumour nodules, the appearances being those of a peripheral carcinoma of the lung. Abdomen. Apart from a previous perforation of the duodenum, there were no abnormalities in the gastrointestinal tract, liver, spleen or kidneys. In particular, there were no metastases on macroscopical examination. Endocrine glands. The pituitary and thyroid glands were normal. The right adrenal was enlarged and contained tumour metastases. The left adrenal was normal in size but also contained tumour metastases. Histological examination showed an anaplastic carcinoma at the apex of the right lung. Both adrenals contained massive secondary tumour deposits with marked destruction of the medulla and cortex and little evidence of surviving cortical cells.

\section{Case no. 4}

\section{H.S. aged 56}

The patient, a heavy smoker with a past history of winter bronchitis for many years, was admitted on 11 January 1971 with a 4-day history of cough, shortness of breath, shivering and a feeling of generalized weakness. He had left-sided chest and abdominal pain that was worse on deep breathing Sputum was mucoid and there was no haemoptysis Weight loss was about $2 \cdot 25 \mathrm{~kg}$.

On examination, in spite of slight dyspnoea at rest, he looked well. Temperature $37.5^{\circ} \mathrm{C}$. There was no clubbing. BP $115 / 90 \mathrm{~mm} \mathrm{Hg}$, pulse $120 / \mathrm{min}$. There were a few rhonchi at the left lung base. The abdomen was normal, but the right testis was noted to be slightly enlarged and firm.

Investigations. On admission chest X-ray showed pleural calcification at the left base. ECG showed right axis deviation. Sputum-no pathogens. No AFB seen. Hb $15.5 \mathrm{~g} / 100 \mathrm{ml}$, WBC 3900-normal differential, ESR $35 \mathrm{~mm} / 1 \mathrm{hr}$.

Progress. He was treated as having an acute respiratory infection, with ampicillin $500 \mathrm{mg} 6$ hourly. He appeared to improve. On the day after admission the electrolyte pattern was: blood urea $68 \mathrm{mg} / 100 \mathrm{ml}$, $\mathrm{Na} 121 \mathrm{mEq} / \mathrm{l}, \mathrm{K} 4.8 \mathrm{mEq} / 1, \mathrm{TCO}_{2} 25 \mathrm{mEq} / 1$.

Further enquiry at this stage revealed no relevant family history, but on direct questioning he did complain of cramps in the left forearm and left thigh present for 6 months. There was no pigmentation. One day later the electrolyte pattern was: blood urea $63 \mathrm{mg} / 100 \mathrm{ml}, \mathrm{Na} 114 \mathrm{mEq} / 1, \mathrm{~K} 4.3 \mathrm{mEq} / 1$, $\mathrm{TCO}_{2} 21 \mathrm{mEq} / \mathrm{l}$. A diagnosis of Addison's disease was considered, but a morning plasma cortisol on the same day was $20.5 \mu \mathrm{g} / 100 \mathrm{ml}$ (9.00 a.m.).

Three days after admission the electrolyte pattern was: blood urea $55 \mathrm{mg} / 100 \mathrm{ml}, \mathrm{Na} 120 \mathrm{mEq} / \mathrm{l}$, 
$\mathrm{K} 5.3 \mathrm{mEq} / 1, \mathrm{TCO}_{2} 14 \mathrm{mEq} / 1$. The patient collapsed and died later the same day.

Necropsy was performed 4 days after death. No abnormal pigmentation of the skin and mucosae was found. Thorax. The heart was not enlarged but showed severe atherosclerosis of the coronary arteries. Diffuse fibrous adhesions were present with complete obliteration of the pleural spaces and calcified hyaline plaques on the parietal layer. The lungs were slightly oedematous and the left lower lobe contained a small calcified nodule measuring $4 \mathrm{~mm}$ in diameter. The tracheobronchial lymph nodes were enlarged. Abdomen. The gastro-intestinal tract, liver, spleen and kidneys appeared macroscopically normal. Genital tract. The epididymes were considerably enlarged and contained abundant caseous material. Endocrine glands. The pituitary and thyroid gland showed no abnormality. The left adrenal was difficult to dissect from its surrounding fat tissue; the gland was atrophic, showing complete loss of cortical and medullary markings. The right adrenal was markedly enlarged and contained abundant caseous material replacing its normal contents. Central nervous system. No macroscopic abnormality.

Histological examination. The liver, spleen, lungs and epididymes contained caseating tuberculous granulomas and acid fast bacilli were identified in several of the sections. The right adrenal gland showed widespread destruction of the gland by caseating tuberculosis. Some surviving cortical cells, which appeared to be degenerating, were found but owing to the complete loss of architectural pattern of the gland, it was difficult to tell to which zone of the cortex these surviving but diseased cells originally belonged; however, few of these appeared to retain an arrangement similar to the one found in the zona glomerulosa in normal circumstances. No cells from the medulla could be identified. The left adrenal gland was markedly atrophic, with complete loss of normal architecture. It showed no evidence of active tuberculosis and acid fast bacilli were not identified. However, calcification and patchy areas of fibrosis were present, both changes possibly representing fairly old tuberculous disease. Some surviving but degenerating cells, similar to those found in the right adrenal, were also present, in even lesser numbers.

\section{Discussion}

It is reasonable to suggest that diagnosis might have been made sooner if pigmentation had been present in these patients. The presence of pigmentation has always been considered a cardinal sign in Addison's disease and it has been variably recorded as being present in 100, 97 and $95 \%$ of cases (Dunlop, 1963; Talbot et al., 1952; Mattingly, 1968). Many standard textbooks (Cecil \& Loeb, 1971 ; Symington,
1969; Boyd, 1970) refer to pigmentation as a classical feature of the disease. A review of the world literature revealed very little comment on a form of Addison's disease without pigmentation, although several cases have been recorded in the last 30 years (Zubor, 1967; Felix-Davies, 1955; Lawson, Becks \& Murphy, 1943; Van Buchem \& Arends, 1955).

In reviewing our own four cases, it is seen that a diagnosis of Addison's disease was only made late in the course of the illness in two patients and both these patients died (Cases 3 and 4). At necropsy, one patient (Case 3) showed a small peripheral carcinoma of the lung and the only demonstrable metastases were in the adrenal glands. The other patient (Case 4) who died, had miliary tuberculosis with caseating tuberculosis of the right adrenal gland and atrophy of the other gland. Histologically the appearances of the left gland suggested previous tuberculous infection. The two patients who survived were found to have adrenal antibodies.

There seems to be very little study relating the duration of the disease to the presence of pigmentation. It has been suggested that duration of the illness is a major factor (Guttman, 1930) and in particular the time taken to stimulate the pituitary to produce ACTH (Van Buchem \& Arends, 1955).

Case 4 had undoubtedly had previous tuberculous infection and the miliary process present at the time of death may have been there for some months or at least for sufficient time for pigmentation to occur. Alternatively, the final electrolyte figures could have been explained on the basis of an inappropriate ADH secretion sometimes seen in miliary tuberculosis, and adrenal failure could well have been only terminal. In this case and Case 2, the circulating level of cortisol was normal and this would undoubtedly inhibit any feed-back stimulus to the pituitary thereby preventing excess production of ACTH. Case 1 showed evidence of ovarian failure for several years in the form of amenorrhoea. Ovarian and adrenal antibodies were detected in this case and it might be reasonable to conclude that these had been present for many years. She also had a very high level of circulating ACTH which is usually associated with the appearance of pigmentation. Cases 2 and 3 had seemingly short illnesses, although in Case 2 the adrenal antibodies may have been present for some months. In Case 3, however, the illness was short and this could explain the lack of pigmentation. Finally we would suggest that the factors involved in the appearance of pigmentation are variable and in particular high circulating levels of ACTH and duration of the illness may not be the major factors.

The failure to find pigmentation could be due to a failure to look carefully for it, but pigmentation was specifically looked for in all four cases. Our four 
patients were Caucasian, but racial pigmentation may make the diagnosis difficult. Feiwel (1969) describes four cases of Addison's disease that initially went unnoticed in a skin department, even when skin pigmentation was present.

Finally, although pigmentation is a very useful sign in Addison's disease, its absence by no means excludes the diagnosis. It seems that only an awareness of the possibility of the disease will lead to an early diagnosis. Apart from the lack of pigmentation, all four of our cases had unusual presentations: Case 1 presented with amenorrhoea and only the development of an 'Addisonian crisis' prompted the diagnosis. Case 2 presented with a severe head injury and the associated hyponatraemia was initially attributed to inappropriate ADH secretion. Case 3 presented with hypoglycaemia. Case 4 presented with what appeared to be a simple chest infection. We would emphasize the close scrutiny of all 'routine' electrolyte results and the importance of a dynamic screening procedure such as a Synacthen test at the earliest possible opportunity (James \& Landon, 1968). It is not sufficient to rely on a resting level of plasma cortisol as this will not indicate the degree of adrenal reserve. This is shown in Cases 2 and 4 where the resting levels were within the normal range. These two patients were probably both stressed maximally at the time of their admission.

\section{Acknowledgments}

We are grateful to Dr R. D. Green, Dr C. A. Young and Dr P. A. Zorab for permission to report patients under their care.

\section{References}

Boyd, W. (1970) A Textbook of Pathology, 8th edn, p. 465. Kimpton, London.

British Medical Journal (1963) Leading article. Diagnosis and management of hypoadrenalism, $2,882$.

CeCIL, R.L. \& LOEB, R.F. (1971) Textbook of Medicine, 13th edn, p. 1317. Saunders, Phiadelphia.

Dunlop, D. (1963) Eighty-six cases of Addison's disease. British Medical Journal, 2, 887.

FeIwel, M. (1969) Failure to diagnose Addison's disease and the value of tetracosactrin (Synacthen) stimulation tests Transactions of St John's Hospital Dermatological Society, 55, $1,74$.

Felix-Davies, D. (1955) Addison's disease presenting as loss of weight without pigmentation. Proceedings of Royal Society of Medicine, 48, 1024.

Guttman, P.H. (1930) Addison's disease. A statistical analysis of 566 cases and a study of the pathology. Archives of Pathology, 10, 742.

JAMES, V.H.T. \& LANDON, J. (1968) Recent Advances in Endocrinology, 8th edn, p. 62. J. A. Churchill, London.

LAwson, H.M., BeCKS, I.A. \& MurPhy, R.G. (1943) Addison's disease. Report of a fatal case. New England Journal of Medicine, 228, 480.

Mattingly, D. (1968) In: Recent Advances in Medicine, 15 th edn, p. 146. J. A. Churchill, London.

Symington, T. (1969) Functional Pathology of the Human Adrenal Gland, 1st edn, p. 160. E. Livingstone, London.

Talbot, N.B., Sobel, E.H., McArthur, J.W. \& Crawford, J.D. (1952) Functional Endocrinology, p. 196. Harvard University Press.

VAN Bichem, F.S.P. \& Arends, A. (1955) Skin pigmentation in patients with hypofunction of the adrenal glands. Acto medica scandinavica, 152, 81.

Zubor, N.A. (1967) On the diagnosis of a pigment free form of Addison's disease. Klinicheskaya Meditsina, Moskva, 45, 144. 